\title{
Volatile hydrocarbons from endophytic fungi and their efficacy in fuel production and disease control
}

\author{
B. Shankar Naik
}

\begin{abstract}
Endophytic fungi are the microorganisms which asymptomatically colonize internal tissues of plant roots and shoots. Endophytes produce a broad spectrum of odorous compounds with different physicochemical and biological properties that make them useful in both industry and agriculture. Many endophytic fungi are known to produce a wide spectrum of volatile organic compounds with high densities, which include terpenes, flavonoids, alkaloids, quinines, cyclohexanes, and hydrocarbons. Many of these compounds showed anti-microbial, anti-oxidant, anti-neoplastic, anti-leishmanial and anti-proliferative activities, cytotoxicity, and fuel production. In this review, the role of volatile compounds produced by fungal endophytes in fuel production and their potential application in biological control is discussed.
\end{abstract}

Keywords: Endophytic fungi, Biocontrol, Biofuel, Mycodiesel, Volatile organic compounds

\section{Background}

Endophytic fungi are the microorganisms, which asymptomatically colonize the internal tissues of plant roots and shoots (Bacon and White 2000). Endophytes provide beneficial effects on host plants in deterring pathogens, herbivores, increased tolerance to stress drought, low soil fertility, and enhancement of plant biomass (Redman et al. 2002; Rodrigues et al. 2008 and Ghimire et al. 2011). Plants have many mechanisms to limit the growth of endophytes by producing a variety of toxic metabolites, but over a long period of co-evolution, the host-endophyte may develop genetic systems, allowing for transfer of information themselves, and endophytes have gradually formed a variety of tolerant mechanisms towards host metabolites by producing exoenzymes, mycotoxins, enormous secondary metabolites, and volatile compounds (Tan and Zou 2001; Schulz et al. 2002; Shankar Naik et al. 2006; Newman and Cragg 2015 and Muller et al. 2013). These secondary metabolites are related to terpenes, flavonoids, alkaloids, quinines, cyclohexanes, and hydrocarbons. Many of these shown anti-microbial, anti-oxidant, anti-neoplastic, anti-leishmanial and anti-proliferative

Correspondence: shankar_sbn@yahoo.co.in

Department of Applied Botany, Kuvempu University, Jnana Sahyadri, Shankaraghatta, Karnataka 577 451, India activities, and cytotoxicity (Firakova et al. 2007; Korpi et al. 2009; Kharwar et al. 2011; Zhao et al. 2016 and Wu et al. 2016).

Volatile organic compounds (VOCs) are a large group of carbon-based chemicals with low molecular weights and high vapor pressure produced by living organisms as part of their metabolic process (Bennett and Inamdar 2015). Several biodiesel hydrocarbons are terpenes, a chemically diverse class of high-density compounds produced by plants, fungi, and bacteria. Due to their high energy densities, terpenes (e.g., pinene and bisabolene) are actively being investigated as potential 'drop-in' biofuels for replacing diesel and aviation fuel (Wu et al. 2016).

The composition of all biodiesel fuels is straight chained hydrocarbons like hexane, heptanes, octane, nonane, and decane along with many other compounds including branched alkanes, cyclic alkanes, a plethora of benzene derivatives, and poly aromatic hydrocarbons (Campos et al. 2010 and Song et al. 2000). Several reviews (Kramer and Abraham 2012 and Morath et al. 2012) have reported on endophytic fungal VOCs and their potential for biotechnological applications in biofuel production, antibiotics against human pathogen, biosensors, flavor, and fragrance additives in development of sustainable agriculture (Wheatley 2002 and Zhi-Lin et al. 2012). 
The importance of fungal volatile compounds in fuel production and their efficacy in biological control have been emphasized with comprehensive chemical analyses (Dennis and Webster 1971 and Stoppacher et al. 2010). Currently, different methods are being used to assess VOCs from fungi which include GC-MS (gas chromatography-mass spectroscopy) (Matysik et al. 2009 and Wani et al. 2010), solid-phase micro extraction (SPME) (Zhang and Li 2010), headspace-SPME GC-MS (Stoppacher et al. 2010), selected ion flow tube-mass spectrometry (SIFT-MS) (Senthilmohan et al., 2001), the proton transfer reaction-mass spectrometry (PTR-MS) (Ezra et al. 2004), and E-nose (Wilson and Baietto 2009 and Booth et al. 2011) etc.

\section{Volatile compounds with biofuel potential}

Fungal endophytes produce a broad spectrum of volatile compounds with different physicochemical and biological properties that make them useful in industry, agriculture, and pharmacy (Yuan et al. 2012) (Table 1). Volatile organic compounds with high energy densities have potential energy applications, which have been described as mycodiesel (Strobel 2014). Endophytic fungi of several Ascomycota lineages (especially members of Xylariaceae) are found to be capable of producing hydrocarbons (Strobel et al. 2001). The genus Muscodor (e.g., M. albus) has evoked general interest among mycologists due to its obligate endophytism, comprehensive spectrum of antimicrobial activity, and fuel production (Strobel et al. 2001). Gliocladium roseum (NRRL 50072) (now Ascocoryne sarcoides) (Griffin et al. 2010) is known to produce a series of volatile hydrocarbons and hydrocarbon derivatives (e.g., heptane, octane, benzene, and some branched hydrocarbons) on both oatmeal and cellulose-based agar medium (Strobel et al. 2008). An endophytic fungus Hypoxylon sp. (CI-4A) was isolated as its imperfect stage (Nodulisporium sp.) from Persea indica (an evergreen tree native to the Canary Islands). On cultivating this fungus on PDA plates, the volatiles produced by this fungus were primarily consisted of 1,8-cineole and 1-methyl-1,4-cyclohexadiene and compounds of high densities (Tomsheck et al. 2010). Ahamed and Ahring (2011) reported production of hydrocarbons from Gliocladium culture directly from cellulosic biomass. The GC-MS-SPME of head space gases from Gliocladium cultures demonstrated the production of C6-C19 hydrocarbons. Hydrocarbon production was 100-fold higher in co-cultures of Gliocladium and Escherichia coli than in pure cultures of Gliocladium. An unusual Phomopsis sp. was isolated as endophyte of Odontoglossum sp. (Orchidaceae) associated with a cloud forest in Northern Ecuador. This fungus produces a monoterpene known as sabinene isolated only from higher plants earlier. In addition, some of the other more abundant VHCs recorded by GC-MS in this organism were 1-butanol, 3-methyl; benzene-ethanol; 1-propanol, 2-methyl and 2-propanone (Singh et al. 2011). Gianoulis et al. (2012) characterized A. sarcoides, using transcriptomic and metabolic data, to establish a hypothetical base for biofuel production pathways. Hassan et al. (2012) selected endophytic Hypoxylon sp. (strain CI-4) and exposed to the epigenetic modulators suberoylanilide hydroxamic acid (SAHA, a histone deacetylase) and 5-azacytidine (AZA, a DNA methyl transferase inhibitor). The GC-MS analyses of the VHCs produced by the variants produced the terpenes including several primary and secondary alkanes, alkenes, organic acids, and derivatives of benzene.

An endophytic Nodulisporium sp. has been isolated from Myroxylon balsamum found in the upper Napo region of the Ecuadorian Amazon. This fungus produces 1,4-cyclohexadiene, 1-methyl-, 1-4 pentadiene and cyclohexene, 1-methyl-4-(1-methylethenyl)-along with some alcohols and terpenoids of interest as potential fuels under microaerophilic growth environments (Mends et al. 2012). The fungus was scaled up in an aerated large fermentation flask, and the VHCs trapped by Carbotrap technology and analyzed by headspace SPME and fiber-GC-MS. Under these conditions, Nodulisporium sp. produced a series of alkyl alcohols, a few terpenoids, and some hydrocarbons (Mends et al. 2012). Nodulisporium sp. (Hypoxylon sp.) was also isolated as an endophyte of Thelypteris angustifolia (broadleaf leaf maiden fern) in a rainforest region of Central America. This fungus uniquely produces a series of ketones. The most abundant identified compound was 1,8 cineole, 1-butanol, 2-methyl, and phenyl ethanol alcohol and most importantly cyclohexane, propyl, which is a common ingredient of diesel fuel when cultured on PDA. Furthermore, the volatiles of the isolate Nodulisporium sp. were selectively active against a number of plant pathogens including Daldina sp. and Hypoxylon spp. teleomorphs (seems to produce its own unique set of VOCs) (Hassan et al. 2013). Wu et al. (2016) characterized 26 terpene synthases (TPSs) derived from four endophytic (Xylariaceous) fungi known to produce mycodiesel hydrocarbons. Shaw et al. (2015) suggested the evolutionary relationship of fungal terpene synthases to those in plants and bacteria. Authors identified 1,8-cineole, a commercially important monoterpenes from endophytic Hypoxylon sp.

\section{Biological control potential of volatile compounds}

Volatile compounds are typically lipophilic liquids with high vapor pressures. These are lethal to a wide variety of plant and human pathogenic fungi and bacteria and are also effective against nematodes and certain insects (Strobel 2006 and Grimme et al. 2007) (Table 1). Emission of volatiles by bacteria and fungi has been known 


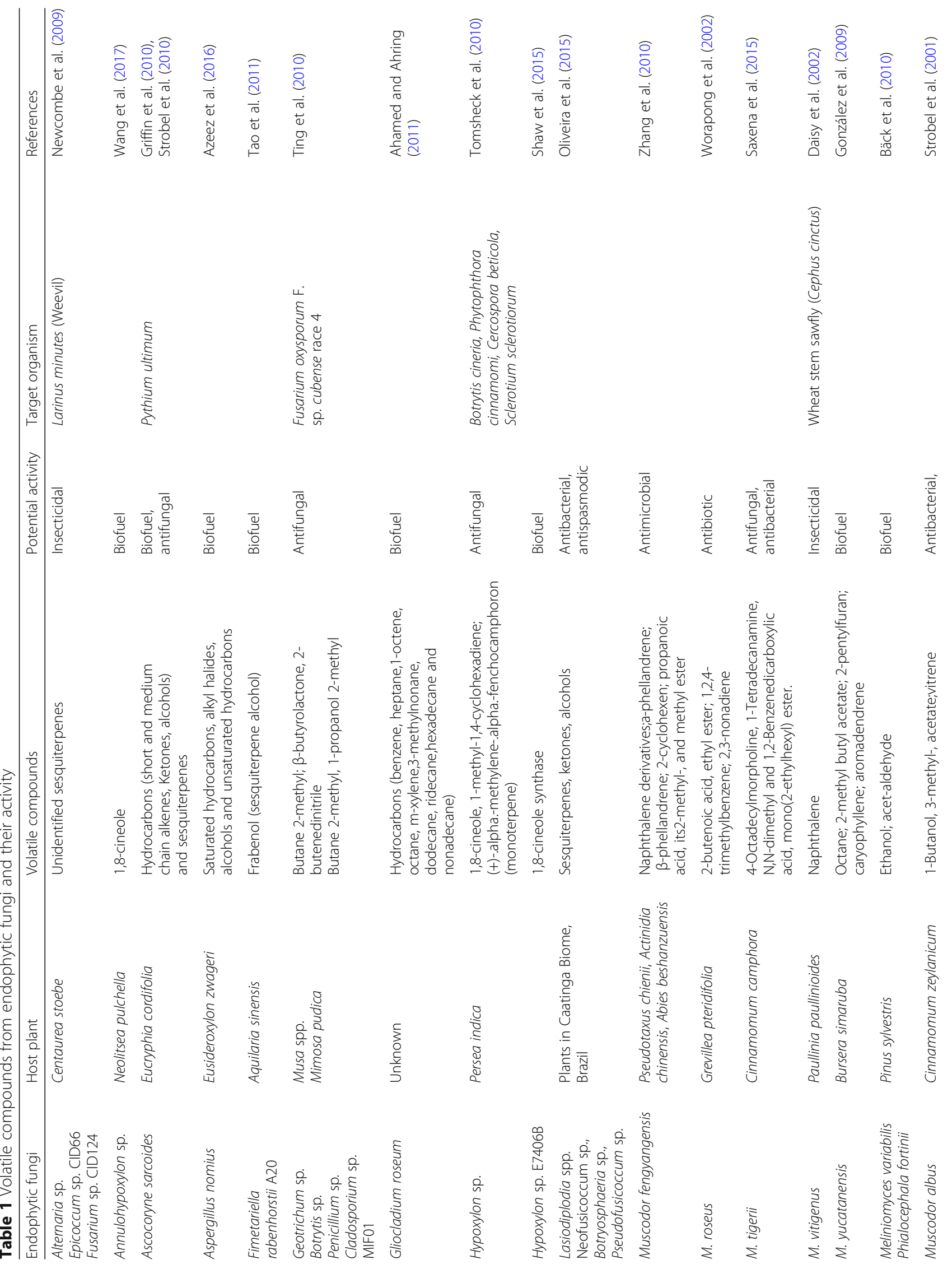




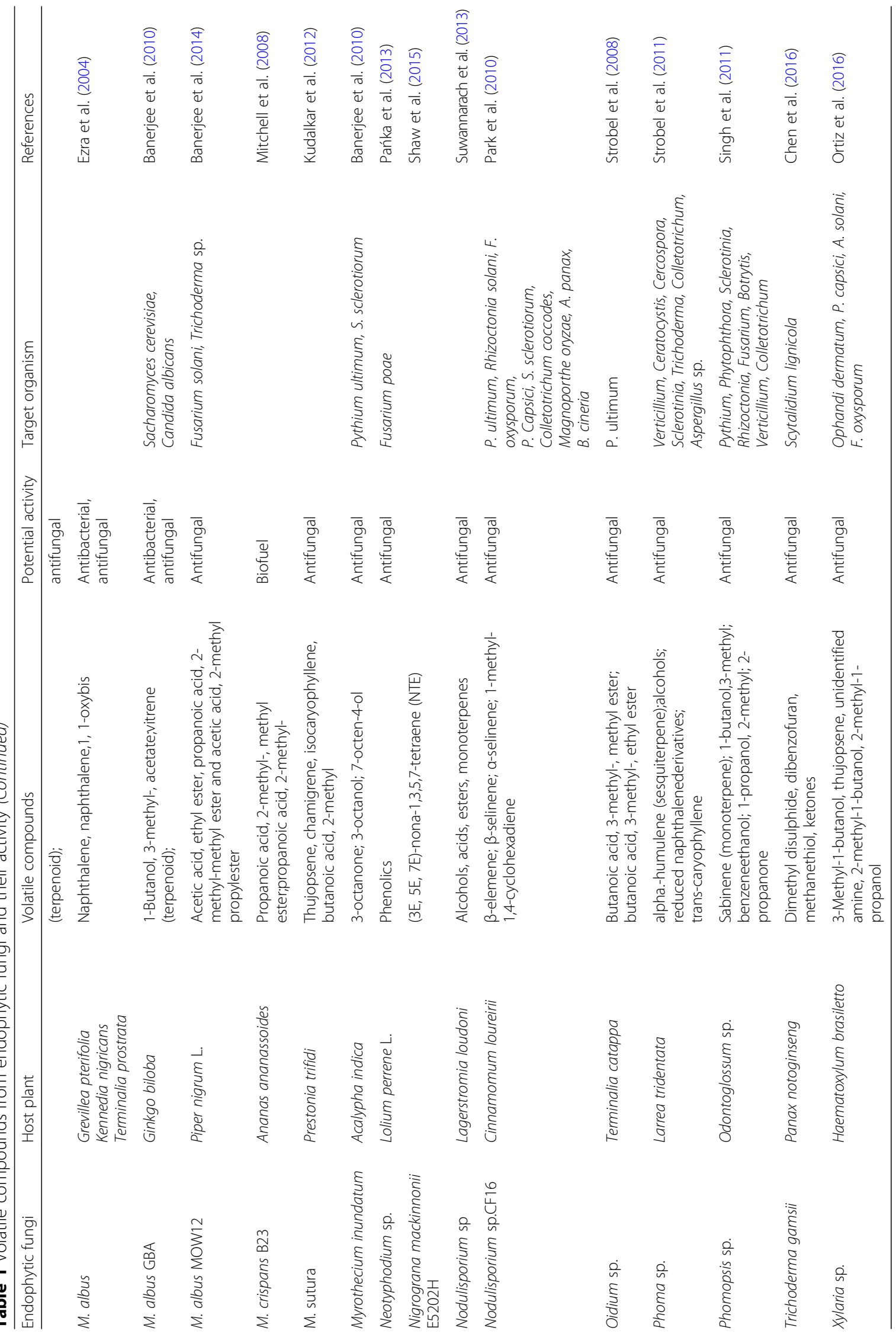


and reviewed by many authors for a long time (Kai et al. 2009). Volatile production is species-specific and serve as info chemicals for inter-and intra-organismic communication, cell-to-cell communication signals, a possible carbon release valve, or growth-promoting or growth-inhibiting agents (Kai et al. 2009). The inhibitory mode of action, when it involves one plant pathogen among interacting organisms, will be of interest in biological control. Strobel et al. (2001) reported that the volatiles produced by endophytic fungus $M$. albus inhibited the germination of the teliospores of Tilletia horrida, T. indica, and T. tritici (pathogenic fungi cause the plant diseases rice kernel smut, wheat kernel bunt and wheat common bunt, respectively). The VOC molecules produced from $M$. albus were 1-butanol, 3-methyl-acetate, esters, alcohols, acids, lipids, and ketones. The most effective class of inhibitory compounds tested against fungi was the esters, of which 1-butanol, 3-methyl-acetate was the most biologically active, reducing growth of Cercospora beticola, Fusarium solani, Pythium ultimum, Rhizoctonia solani, Sclerotinia sclerotiorum, Tapesia yallundae, and Xylaria sp. (Strobel et al. 2001). An endophytic isolate of Gliocladium sp. was obtained from the Patagonian Eucryphiacean tree $(\mathrm{Eu}$ cryphia cordifolia), producing a mixture of volatile organic compounds (VOCs) lethal to plant pathogenic fungi such as Pythium ultimum and Verticillium dahliae. Some of the volatile bioactive compounds exuded by Gliocladium sp. (1-butanol, 3-methyl-, phenylethyl alcohol and acetic acid, 2-phenylethyl ester, and various propanoic acid esters) are also produced by Muscodor albus, a well-known volatile antimicrobial producer (Stinson et al. 2003).

Soil fungistasis is a natural process in which fungal propagules fail to survive under favorable temperature and moisture content (Morath et al. 2012). Several VOCs such as trimethyl amine, 3-methyl-2-pentanone, dimethyl di sulphide-methyl pyrazine, 2,5-dimethyl-pyrazine, $\mathrm{N}$-dimethyl octyl-amine and nonadecane (Xu et al. 2004 and Garbeva et al. 2011) inhibited three fungal species Paecilomyces lilacinus, Pochonia chlamydospora, and Clonostachys rosea in the soil suggesting that direct competition is not needed for microbial interaction $(\mathrm{Xu}$ et al. 2004).

Fungal pathogen Rhizoctonia solani, which causes damping off of broccoli and Phytophthora casici, which causes root rot of bell pepper, could not be able to survive in the soil consisting of $M$. albus (Mercier and Manker 2005). In addition, fungal VOCs stimulate or enhance soilborne biocontrol agents (Wheatley 2002). The VOCs of Trichoderma atroviridae increase the expression of a primary biocontrol gene of Pseudomonas flourescencs (Lutz et al. 2004). The VHCs of endophytic fungi may also benefit the host plant by production of additional line of defense against pathogens of their host plants (Rubalcava et al. 2010). The fungi in genus
Muscodor produces VHCs that inhibit and kill various plant pathogenic fungi and bacteria. The VHCs of $M$. albus, M. yucatanensis, and M. fengyangensis inhibited pathogenic species of bacteria fungi and oomycetes (Strobel et al. 2001; Atmosukarto et al. 2005 andZhang et al. 2010). The culture of M. crispans produces hydrocarbons that inhibited Mycosphearella fijiensis (causes black sigatoka disease in bananas) and Xanthomonas axonopodis pv.citri (a bacterial pathogen of citrus) (Mitchell et al. 2010). An endophytic Phoma sp. isolated from Creosote bush (Larrea tridentata) emits volatile compounds such as transcaryophyllene, a series of sesquiterpenoids, some alcohols, and naphthalene derivatives, which inhibited or killed isolates belonged to Cercospora, Ceratocystis, Sclerotinia, and Verticillium (Strobel et al. 2011). The extracts of endophytic fungi Colletotrichum truncatum isolated from oil seed crop Jatropa curcas produce volatile compounds effective against Fusarium sclerotiorum (Kumar and Kaushik 2013). Rubalcava et al. (2010) reported allelochemical effects of volatile hydrocarbons from tropical endophytic fungi M. yucatanensis isolated from Bursera simaruba growing in forests of Mexico. The VOCs were lethal to Alternaria solani, Colletotrichum sp., Giugnardia mangifera, Phomopsis sp., Phytophthora capsici, Phytophthora parasitica, and Rhizoctonia sp. New fungitoxic sesquiterpenoids, chokols A-G, have been isolated from Epichloe typhina, an endophytic fungus of Phleum pratense, and have been found to be toxic to the leaf spot disease pathogen Cladosporium phlei (Koshino et al. 1989). Other endophytic fungi isolated from plum (Prunus domestica) leaves showed antagonistic activity against Monilinia fructicola (Pimenta et al. 2012).

Post-harvest diseases often result in serious loss during storage of fruits and vegetables. The application of microbial antagonists is generally considered as a safe and eco-friendly alternative to control fruit spoilage (Jamalizadeh et al. 2011). Sulphur dioxide $\left(\mathrm{SO}_{2}\right)$ and ozone $\left(\mathrm{O}_{3}\right)$ are often used as fumigants for control of post-harvest decay (Gabler et al. 2010). $\mathrm{SO}_{2}$ and $\mathrm{O}_{3}$ have disadvantages over the large-scale commercial use, and fruits are more likely to be attacked by pathogens again after fumigation (Gabler et al. 2006). The volatiles produced by endophytic fungi can overcome these limitations and represent an attractive and promising biofumigation option for organic food production (Zhi-Lin et al. 2012). Microbial antagonists can effectively control fruit spoilage and minimizes the loss. Volatiles offer safe and effective strategy for controlling the post-harvest diseases. The volatiles possess long distance mechanism of antagonistic action leading to direct penetration at spatial scales (Fialho et al. 2011) without spraying or drenching as application methods (Park et al. 2010). The volatiles of M. Albus are useful for the control of post-harvest 
plant diseases which is popularly known as "mycofumigation" (Stinson et al. 2003). Some endophytic fungal volatiles effectively inhibit or kill the most common postharvest fruit pathogens (Gabler et al. 2006; Lee et al. 2009 and Park et al. 2010), including species of Botrytis cinerea (gray mold), Penicillium expansum (blue mold), Sclerotinia sclerotiorum (white mold), and Monilinia fructicola (brown rot) (Kanchiswamy et al. 2015). The volatiles produced by endophytic fungi have been used to replace methyl bromide ( $\mathrm{MeBr}$ ), a traditional soil fumigant that is now being banned in many parts of the world because its involvement in depletion of ozone layer. Both greenhouse and field trials showed that Muscodor spp. were effective in reducing soilborne disease severity in many crops and vegetables, including Phytophthora blight (Phytophthora capsici), common bunt of wheat (Tilletia caries), damping-off (Rhizoctonia solani), and root rot (Pythium ultimum) (Camp et al. 2008; Mercier and Jiménez 2009; Worapong and Strobel 2009; Goates and Mercier 2011). Additionally, the volatiles of Oxyporus latemarginatus EF069, an endophyte isolated from red pepper, inhibited the mycelial growth of several plant pathogens, which are known to damage post-harvest fruits (Lee et al. 2009). The volatiles of $O$. latemarginatus EF069 reduced post-harvest decay of apples caused by B. cinerea and Rhizoctonia root rot of moth orchid (Lee et al. 2009). Endophytic Nodulisporium sp. CMU-UPE34 isolated from Lagerstromia loudoni is able to produce 31 different volatiles especially eucalyptol. This fungus is able to inhibit or kill 12 different plant pathogens including control of green mold decay on Citrus limon caused by Penicillium digitatum, blue mold decay of Citrus aurantifolia and Citrus reticulata caused by P. expansum (Suwannarach et al. 2013).

Fungal volatiles could serve as signaling molecules ("info chemicals" or "semio-chemicals") as pheromones, allomones, kairomones, food sources, and attract insects (Rohlfs et al. 2005 and Mburu et al. 2011). Emission of VHCs produced by Trametes gibbosa (wood-rotting white rot fungus) serves as an attractant for fungus-eating beetles (Coleoptera) (Kline et al. 2007 and Thakeow et al. 2008). The $M$. albus VHCs demonstrated nematostatic and nematicidal properties. It has shown a great capacity to control of the root-knot nematode Meloidogyne incognita (Grimme and Zidack 2007). Riga et al. (2008) tested the VHCs produced by the fungus M. albus and found in vitro mortality of Paratrichodorus allius, Pratylenchus penetrans, and Meloidogyne chitwoodi. The VHCs produced by $M$. albus were capable of inhibiting the development of the pupal stage of $P$. operculella and cause mortality in several growth stages of the codling moth (Lepidoptera) (Lacey et al. 2009). Fumigation with VHCs produced by $M$. albus for 3 days caused mortality of codling moth adults and neonate larvae, and it was reported that VHCs, including nitrosoamides produced by Muscodor spp., were highly efficient at killing insects (Strobel (2011); Schalchli et al. 2016). M. vitigenus produces naphthalene, an effective insect repellent (Daisy et al. 2002). Liarzi et al. (2016) reported the biological activities of VOCs produced from Daldinia cf. concentrica, an endophytic fungi isolated from olive tree (Olea europaea L.) grown in Israel. The GC-MS analysis of volatiles produced from this fungus led to identification of 27 VOCs. The post-harvest experiments demonstrated that $D$. cf. concentrica prevented development of molds on organic dried fruits and also eliminated Aspergillus niger infection in pea nuts (Liarzi et al. 2016).

\section{VOCs in controlling human pathogens}

Endophytes have recently attracted a great attention due to their production of strong antimicrobial volatile compounds. Muscodor species are known to produce five classes of volatiles (acids, alcohols, esters, ketones, and lipids). M. albus emitted a number of volatiles such as tetrohydrofuran, aciphyllene, and an azulene derivative. The volatiles produced by $M$. albus effectively inhibited or killed a wide range of plant and human pathogenic bacteria (Atmosukarto et al. 2005) and fungi such as Aspergillus fumigates and Candida albicans (Strobel et al. 2001 and Schmidt et al. 2015). The VOCs of M. crispans isolated from wild pineapple known to antagonistic against several human pathogens including Yersinia pestis, Mycobacterium tuberculosis, and Staphylococcus aureus. (Mitchell et al. 2010). Another endophyte, M. fengyangensis, has the ability to kill pathogenic E. coli (Zhang et al. 2010 and Yuan et al. 2012). The majority of fungal VOCs from endophytic fungi are used as controlling fungal deterioration of crops, fruits, and vegetables under pre and post-harvest conditions. However, presently, these volatiles are not being actively applied to humans in controlling fungal infections (Deshmukh et al., 2018).

\section{Conclusions}

Endophytic fungi represent a relatively untapped pool of wide array of metabolites with potential applications. Volatiles represent a new frontier in bioprospect avenues. The study of these gas-phase compounds promises the discovery of new products for human exploitation in fuel production, biocontrol, plant growth, and biotechnology. Technological advances with respect to profiling and analyzing VOCs; genome sequencing and functional genomics tools; and way forward studying the molecular, physiological, and cellular changes in plant and microbial systems will open a new area of research on volatiles of immense applications. 


\section{Acknowledgements}

The author greatly acknowledges University Grants Commission, India, for the financial support.

\section{Funding}

UGC (University Grants Commission, India) provided the financial support to BSN.

\section{Author's contribution}

The author read and approved the final manuscript.

\section{Ethics approval and consent to participate}

Not applicable.

\section{Consent for publication}

Not applicable.

\section{Competing interests}

The authors declare that they have no competing interests.

\section{Publisher's Note}

Springer Nature remains neutral with regard to jurisdictional claims in published maps and institutional affiliations.

Received: 13 April 2018 Accepted: 2 August 2018

Published online: 22 August 2018

\section{References}

Ahamed A, Ahring BK (2011) Production of hydrocarbon compounds by endophytic fungi Gliocaldium sp. grown on cellulose. Bioresour Technol 102: 9718-9722

Atmosukarto I, Castillo U, Hess W, Sears J, Strobel G (2005) Isolation and characterization of Muscodor albus; a volatile antibiotic producing fungus. Plant Sci 169:854-861

Azeez LA, Muid S, Hasnul BM (2016) Identification of volatile secondary metabolites from an endophytic microfungus Aspergillus nomius KUB105. Malaysian J Anal Sci 20(4):751-759

Bäck J, Aaltonen H, Hellen H, Kajos MK et al (2010) Variable emissions of microbial volatile organic compounds (MVHCs) from root-associated fungi isolated from Scots pine. Atmos Environ 44:3651-3659

Bacon CW, White JW (2000) Microbial endophytes. Marcel Dekker, New York

Banerjee D, Pandey A, Jana M, Strobel GA (2014) Muscodoralbus MOW12 an endophyte of Piper nigrum L. (Piperacae) collected from North east India produces volatile antimicrobials. Indian J Microbiol 54:27-32

Banerjee D, Strobel GA, Booth E, Geary B et al (2010) An endophytic Myrothecium inundatum producing volatile organic compounds. Mycosphere 1:229-240

Bennett JW, Inamdar AA (2015) Are some fungal volatile organic compounds (VHCs) mycotoxins? Toxins 7:3785-3804

Booth E, Strobel G, Knighton B, Sears J et al (2011) A rapid column technique for trapping and collecting of volatile fungal hydrocarbons and hydrocarbon derivatives. Biotechnol Lett 33:1963-1972

Camp AR, Dillard HR, Smart CD (2008) Efficacy of Muscodoralbus for the control of Phytophthora blight of sweet pepper and butternut squash. Plant Dis 92: 1488-1492

Campos VP, Canuto de Pinho RS, Freire ES (2010) Volatiles produced by interacting microorganisms potentially useful for the control of plant pathogens. Ciêncagrotec 34:525-535

Chen JL, Sun SJ, Miao CP, Wu K et al (2016) Endophytic Trichoderma gamsii YIM PH30019: a promising biocontrol agent with hyperosmolar, mycoparasitism, and antagonistic activities of induced volatile organic compounds on rootrot pathogenic fungi of Panax notoginseng. J Ginseng Res 40:315-324

Daisy BH, Strobel GA, Castillo U, Ezra D et al (2002) Naphthalene, an insect repellent, is produced by Muscodor vitigenus, a novel endophytic fungus. Microbiology 148:3737-3741

Dennis C, Webster J (1971) Antagonistic properties of species groups of Trichoderma: II. Production of volatile antibiotics. Trans Br Mycol Soc 57:41-48

Deshmukh SK, Gupta MK, Prakash V, Saxena S (2018) Endophytic fungi: a source of potential antifungal. compounds. J fungi 4(77):1-42.

Ezra D, Jasper J, Rogers T, Knighton B et al (2004) Proton- transfer reaction-mass spectroscopy as technique to measure volatile emissions of Muscodor albus. Plant Sci 166:1471-1477
Fialho MB, Duarte de Moraes MH, Tremocoldi AR, Pascholati SF (2011) Potentia of antimicrobial volatile compounds to control Sclerotinia sclerotiorum in bean seeds. Pesq Agropec Bras 46:137-142

Firakova S, Sturdikova M, Muckova M (2007) Bioactive secondary metabolites produced by microorganisms associated with plants. Biologia 62:251-257

Gabler FM, Fassel R, Mercier J, Smilanick JL (2006) Influence of temperature, inoculation interval, and dosage on biofumigation with Muscodor albus to control post harvest grey mold on grapes. Plant Dis 90:1019-1025

Gabler FM, Mercier J, Jimenez JI, Smilanick JL (2010) Integration of continuous biofumigation with Muscodo ralbus with pre-cooling fumigation with ozone or sulphur dioxide to control post harvest gray mold of table grapes. Postharvest Biol Technol 55:78-84

Garbeva P, Gera Hol WH, Termorshuizen AJ, Kowalchuk GA, Boer W (2011) Fungistasis and general soil biostasis. Soil Biol Biochem 43(3):469-477

Ghimire SR, Charlton ND, Bell JD, Krishnamurthy YL, Craven KD (2011) Biodiversity of fungal endophyte communities inhabiting switchgrass (Panicum virgatum L.) growing in the native tall grass prairie of northern Oklahoma. Fungal Divers 47:19-27

Gianoulis TA, Griffin MA, Spakowicz DJ, Dunican BF et al (2012) Genomic analysis of the hydrocarbon-producing, cellulolytic, endophytic fungus Ascocoryne sarcoides. PLOS Genet 8:1002558

Goates BJ, Mercier J (2011) Control of common bunt of wheat under field conditions with the biofumigant fungus Muscodor albus. Eur J Plant Pathol. https://doi.org/10.1007/s10658-011-9817-z

González MC, Anaya AL, Glenn AE, Macías-Rubalcava MLet al. (2009) Muscodor yucatanensis, a new endophytic ascomycete from Mexican chakah, Bursera simaruba. Mycotaxon 110:363-372

Griffin MA, Spakowicz DJ, Gianoulis TA, Strobel SA (2010) Volatile organic compound production by organisms in the genus Ascocoryne and a re-evaluation of mycodiesel production by NRRL 50072. Microbiology 156:3814-3829

Grimme E, Zidack N (2007) Comparison of Muscodor albus volatiles with a bio rational mixture for control of seedling diseases of sugar beet and root-knot nematode on tomato. Plant Dis 91:220-225

Grimme E, Zlidack NK, Sikora RA, Strobel GA, Jacobson BJ (2007) Comparison of Muscodor albus volatiles with abiorational mixture for control of seedling diseases of sugarbeet and root-knot nematode on tomato. Plant Dis 91:220-225

Hassan R, Strobel GA, Booth E, Knighton Bet al. (2012) Modulation of volatile organic compound formation in the mycodiesel producing endophyteHypoxylon sp. Cl-4. Microbiology 158:465-473

Hassan SR, Strobel GA, Geary B, Sears J (2013) An endophytic Nodulisporium sp. from Central America producing volatile organic compounds with both biological and fuel potential. J Microbiol Biotechnol 23:29-35

Jamalizadeh M, Etebarian HR, Aminian H, Alizadeh A (2011) A review of mechanisms of action of biological control organisms against post-harvest fruit spoilage. EPPO Bull 41:65-71

Kai M, Haustein M, Molina F, Petri A et al (2009) Bacterial volatiles and their action potential. Appl Microbiol Biotechnol 81:1001-1012

Kanchiswamy CN, Malnoy M, Maffei ME (2015) Chemical diversity of microbial volatiles and their potential for plant growth and productivity. https://doi org/10.3389/fpls.2015.00151

Kharwar RN, Mishra A, Gond SK, Stierle A, Stierle D (2011) Anticancer compounds derived from fungal endophytes: their importance and future challenges. Nat Prod Rep 28:1208-1228

Kline D, Allan SA, Bernier UR, Welch CH (2007) Evaluation of the enantiomers of 1-octen-3-ol and 1-octyn-3-ol as attractants for mosquitoes associated with a freshwater swamp in Florida, U.S.A. Med Vet Entomol 21:323-331

Korpi A, Jarnberg J, Pasanen AL (2009) Microbial volatile compounds. Crit Rev Toxicol 39:139-193

Koshino H, Togia S, Yoshihara T, Sakamura S et al (1989) New fungitoxic sesquiterpenoids, chokols A-G, from stromata of Epichloe typhina and absolute configuration of chokol. Agric Biol Chem 53:789-790

Kramer R, Abraham WR (2012) Volatile sesquiterpenes from fungi: what are they good for? Phytochem Rev 11:5-37

Kudalkar P, Strobel G, Riyaz UI-Hassan S, Geary B, Sears J (2012) Muscodor sutura, a novel endophytic fungus with volatile antibiotic activities. Mycoscience 53: 319-325

Kumar S, Kaushik N (2013) Endophytic fungi isolated from oil seed crop Jatropha curcas produces oil and exhibit antifungal activity. PLOS ONE 8:1-8

Lacey L, Horton D, Jones DC, Headrick HL et al (2009) Efficacy of the biofumigation fungus Muscodor albus (Ascomycota: Xylariales) for control of 
codling moth (Lepidoptera: Tortricidae) in simulated storage conditions. J Econ Entomol 102:43-49

Lee SO, Kim HY, Choi GJ, Lee HB et al (2009) Mycofumigation with Oxyporus latemarginatus EF069 for control of postharvest apple decay and Rhizoctonia root rot on moth orchid. J Appl Microbiol 106:1213-1219

Liarzi O, Bar E, Lewinsohn E, Ezra D (2016) Use of endophytic fungus Daldinia cf concentrica and its volatiles as biocontrol agents. PLOS One 11(12):e0168242

Lutz MP, Wenger S, Maurhofer M, Defago G, Duffy B (2004) Signaling between bacterial and fungal biocontrol agents in a strain mixture. FEMS Microbiol Ecol 48:447-455

Matysik S, Herbarth O, Mueller A (2009) Determination of microbial volatile organic compounds (MVHCs) by passive sampling onto charcoal sorbents. Chemosphere 76:114-119

Mburu DM, Ndung'u MW, Maniania NK, Hassanali A (2011) Comparison of volatile blends and gene sequences of two isolates of Metarhizium anisopliae of different virulence and repellence towards the termite Macrotermes michaelseni. J Exp Biol 214:956-962

Mends MT, Yu E, Strobel GA, Hassan SRU et al (2012) An endophytic Nodulisporium sp. producing volatile organic compounds having bioactivity and fuel potential. Journal of Petroleum and Environmental. Biotechnol 3:3

Mercier J, Jiménez JI (2009) Demonstration of the biofumigation activity of Muscodor albus against Rhizoctonia solani in soil and potting mix. BioControl 54:797-805

Mercier J, Manker D (2005) Biocontrol of soil-borne diseases and plant growth enhancement in greenhouse soilless mix by the volatile producing fungus Muscodor albus. Crop Prot 24:355-362

Mitchell AM, Strobel GA, Moore E, Robison R, Sears J (2010) Volatile antimicrobials from Muscodor crispans, a novel endophytic fungus. Microbiol 156:270-277

Mitchell M, Strobel GA, Hess WM, Vargas PN, Ezra D (2008) Muscodor crispans, a novel endophyte from Ananas ananassoides in the Bolivian Amazon. Fungal Divers 31:37-43

Morath SU, Hung R, Bennett JW (2012) Fungal volatile organic compounds: a review with emphasis on their biotechnological potential. Fungal Biol Rev 26:73-83

Muller A, Faubert P, Hagen M, Zu Castell W et al (2013) Volatile profiles of fungichemotyping of species and ecological functions. Fungal Genet Biol 54:25-33

Newcombe G, Shipunov A, Eigenbrode S, Raghavendra AK et al (2009) Endophytes influence protection and growth of an invasive plant. Commun Integr Biol 2:29-3

Newman DJ, Cragg GM (2015) Endophytic and epiphytic microbes as sources of bioactive agents. Front Chem 3:34

Oliveira FC, Barbosa FG, Mafezoli J, Oliveira MCF et al (2015) Volatile organic compounds from Filamentous fungi: a chemotaxonomic tool of the Botrysphaeriaceae family. J Braz Chem Soc 26(11):2189-2194

Ortiz BLS, Sanchez Fernandez RE, Duarte G, Lappe-Oliveras P, Macias Rubalcava ML (2016) Antifungal, anti-oomycete and phytotoxic effects of volatile organic compounds from the endophytic fungus Xylaria sp. strain PB3f3 isolated from Haematoxylon brasiletto. J Appl Microbiol 120:1313-1325

Pańka D, Piesik D, Jeske M, Baturo-Cieśniewska A (2013) Production of phenolics and the emission of volatile organic compounds by perennial ryegrass (Lolium perenneL.)/Neotyphodium Iolii association as a response to infection by Fusarium poae. J Plant Physiol 170:1010-1019

Park MS, Ahn J, Choi GJ, Choi YH et al (2010) Potential of the volatile-producing fungus Nodulisporium sp. CF016 for the control of postharvest diseases of apple. Plant Pathol J 26:253-259

Pimenta RS, Moreirada Silva JF, Buyer JS, Janisiewicz WJ (2012) Endophytic fungi from plums (Prunus domestica) and their antifungal activity against Monilinia fructicola. J Food Prot 75:1883-1889

Redman S, Sheehan KB, Stuot RG, Rodrigues RJ, Henson JM (2002)

Thermotolerance conferred to plnt host and fungal endophyte during mutualistic symbiosis. Science 298:1581

Riga E, Lacey L, Guerra N (2008) Muscodor albus, a potential biocontrol agent against plant-parasitic nematodes of economically important vegetable crops in Washington State, USA. Biol Control 45:380-385

Rodrigues RJ, Henson J, Van Volkenburgh E, Hoy M et al (2008) Stress tolerance in plants via habitat adapted symbiosis. ISME 2:404-416

Rohlfs M, Obmann BR, Petersen R (2005) Competition with filamentous fungi and its implication for a gregarious lifestyle in insects living on ephemeral resources. Ecol Entomol 30:556-563

Rubalcava ML, Hernandez-Bautista H, Oropeza F, Duarte Get al. (2010) Allelo chemical effects of volatile compounds and organic extracts from Muscodor yucatanensis, a tropical endophytic fungus from Bursera simaruba. J Chem Ecol 36:1122-1131
Saxena S, Meshram V, Kapoor N (2015) Muscodortigerii sp. nov.-Volatile antibiotic producing endophytic fungus from the Northeastern Himalayas. Microbiol 65:47

Schalchli H, Tortella GR, Rubilar O, Parra L et al (2016) Fungal volatiles: an environmentally friendly tool to control pathogenic microorganisms in plants. Crit Rev Biotechnol 36(1):144-152

Schmidt R, Cordovez V, de Boer W, Raaijmakers J, Garbeva P (2015) Volatile affairs in microbial interactions. ISME J 9:2329-2335

Schulz B, Boyle C, Draegher C, Rommert AK, Krohn K (2002) Endophytic fungi: source of novel biologically active secondary metabolites. Mycol Res 9:996-1004

Senthilmohan ST, Mcewan MJ, Wilson PF, Milligan DB, Freeman CG (2001) Real time analysis of breath volatiles using SIFT-MS in cigarette smoking. Redox Rep 6:185-187.

Shankar Naik B, Shashikala J, Krishnamurthy YL (2006) Study on the diversity of endophytic communities from rice (Oryza sativa L.) and their antagonistic activities in vitro. Microbiol Res 3:290-296

Shaw JJ, Berbasova T, Sasaki T, Jefferson-George K et al (2015) Identification of a fungal 1,8-CineoleSynthase from Hypoxylon sp. with common specificity determinants to the plant synthases. J BiolChem 290(13):8511-8526

Singh SK, Strobel GA, Knighton B, Geary B et al (2011) An endophytic Phomopsis sp. possessing bioactivity and fuel potential with its volatile organic compounds. Microb Ecol 61:729-739

Song C, Hsu C, Mochida I (2000) Chemistry of Diesel Fuels. Taylor and Francis, NY

Stinson M, Ezra D, Hess WM, Sears J, Strobel G (2003) An endophytic Gliocladium of Eucryphia cordifolia producing selective volatile antimicrobial compounds. Plant Sci 165:913-922

Stoppacher N, Kluger B, Zeilinger S, Krska R, Schumacher R (2010) Identification and profiling of volatile metabolites of the biocontrol fungus Trichoderma atroviridae by HS-SPMS-GC-MS. J Microbiol Methods 81:187-193

Strobel G (2006) Muscodoralbus and its biological promise. J Ind Microbiol Biotechnol 33:514-522

Strobel GA (2011) Muscodor species-endophytes with biological promise. Phytochem Rev 10:165-172

Strobel GA (2014) The story of mycodiesel. Curr Opin Microbiol 19:52-58

Strobel GA, Dirkse E, Sears J, Markworth C (2001) Volatile antimicrobials from Muscodoralbus a novel endophytic fungus. Microbiol 147:2943-2950

Strobel GA, Knighton B, Kluck K, Ren Y et al (2008) The production of myco-diesel hydrocarbons and their derivatives by the endophytic fungus Gliocladium roseum (NRRL 50072). Microbiol 154:3319-3328

Strobel G, Tomshek A, Geary B, Spackowicz D, Strobel S, matter S, Mann R (2010) Endophyte strain NRRL 50072 producing volatile organics is a species of Ascocoryne. Mycology 1(3):187-194.

Strobel GA, Singh SK, Hassan RUL, Mitchell A et al (2011) An endophytic/ pathogenic Phoma sp. from creosote bush producing biologically active volatile compounds having fuel potential. FEMS Microbiol Lett 320:87-94

Suwannarach N, Kumla J, Bussaban B, Nuangmek W, Matsui K, Lumyong S (2013) Biofumigation with the endophytic fungus Nodulisporium spp. CMU-UPE34 to control post harvest decay of Citrus fruit. Crop Prot 45:63-70

Tan RX, Zou WX (2001) Endophytes: a rich source of functional metabolites. Nat Prod Rep 18:448-459

Tao MH, Yan J, Wei XY, Li DL et al (2011) A novel sesquiterpene alcohol from Fimetariella rabenhorstii, an endophytic fungus of Aquilaria sinensis. Nat Prod Commun 6:763-766

Thakeow P, Angeli S, Weißbecker B, Schutz S (2008) Antennal and behavioral response of Cis boleti to fungal odor of Trametes gibbosa. Chem Senses 33: 379-387

Ting ASY, Mah SW, Tee CS (2010) Identification of volatile metabolites from fungal endophytes with biocontrol potential towards Fusarium oxysporum F. sp. cubense Race 4. Am J Agric Biol Sci 5:177-182

Tomsheck AR, Strobel GA, Booth E, Geary B et al (2010) Hypoxylon sp., an endophyte of Persea indica, producing 1,8-cineole and other bioactive volatiles with fuel potential. Microb Ecol 60:903-914

Wang KY, Strobel GA, Yan DH (2017) The production of 1,8-Cineole, a potential biofuel from an endophytic strain of Annulohypoxylon sp. FPYF3050 when growan on Agricultural residues. J Sustain Bioenergy Syst 7:65-84

Wani MA, SanjanaK KDM, Lal DK (2010) GC-MS analysis reveals production of 2phenylethanol from Aspergillus nigerendophytic in rose. J Basic Microbiol 50: 110-114

Wheatley RE (2002) The consequences of volatile organic compound mediated bacterial and fungal interactions. Antonie Van Leewenhoek 81:357-364 
Wilson AD, Baietto M (2009) Applications and advances in electronic-nose technologies. Sensors 9:5099-5148

Worapong J, Strobel GA (2009) Biocontrol of a root rot of kale by Muscodor albus strain MFC2. BioControl 54:301-306

Worapong J, Strobel GA, Daisy BH, Castillo U et al (2002) Muscodor roseus sp. nov. , an endophyte from Grevillea pteridifolia. Mycotaxon 81:463-475

Wu W, Taatjes WT, Alonso-Gutierrez J, Lee TS, Gladden JM (2016) Rapid discovery and functional characterization of terpene synthases from four endophytic Xylariaceae. PLOS ONE 17:1-19

Xu C, MO M, Zhang L, Zhang K (2004) Soil volatile fungistasis and volatile fungistatic compounds. Soil Biol Biochem 36:1997-2004

Yuan Z, Chen Y, Xu B, Zhang C (2012) Current perspectives on the volatileproducing fungal endophytes. Crit Rev Biotechnol 32:363-373

Zhang CL, Wang GP, Mao LJ, Komon-Zelazowska M et al (2010) Muscodor fengyangensis sp. nov.from southeast China: morphology, physiology and production of volatile compounds. Fungal Biol 114:797-808

Zhang Z, Li G (2010) A review of advances and new developments in the analysis of biological volatile organic compounds. Microchem J 95:127-139

Zhao K, Lu Y, Yuyan J, Ma X et al (2016) Advances and prospects of taxol biosynthesis by endophytic fungi. Chin J Biotech 2532(8):1039-1051

Zhi-Lin Y, Yi-Cun C, Bai-Ge X, Long ZC (2012) Current perspectives on the volatile-producing fungal endophytes. Crit Rev Biotechnol 32:363-373

\section{Submit your manuscript to a SpringerOpen ${ }^{\circ}$ journal and benefit from:}

- Convenient online submission

- Rigorous peer review

- Open access: articles freely available online

High visibility within the field

- Retaining the copyright to your article

Submit your next manuscript at $\boldsymbol{\nabla}$ springeropen.com 